\title{
FAKTOR - FAKTOR YANG MEMPENGARUHI MINAT PENGGUNAAN ELECTRONIC MONEY: INTEGRASI MODEL TAM - TPB DENGAN PERCEIVED RISK
}

\author{
Ula Rahmatika \\ Program Studi Akuntansi Fakultas Ekonomi Universitas Negeri Yogyakarta \\ ularahmatika@gmail.com \\ Muhammad Andryzal Fajar \\ Staf Pengajar Program Studi Akuntansi Universitas Negeri Yogyakarta \\ andryzal_fajar@uny.ac.id
}

\begin{abstract}
Abstrak : Faktor - Faktor yang Mempengaruhi Minat Penggunaan Electronic Money : Integrasi Model TAM - TPB dengan Perceived Risk. Tujuan dari penelitian ini adalah untuk mengetahui faktorfaktor yang mempengaruhi minat penggunaan e-money. Jenis penelitian ini merupakan penelitian kuantitatif. Sampel penelitian ini adalah 260 responden mahasiswa Universitas Negeri Yogyakarta. Sampel diambil menggunakan teknik convinience sampling. Metode analisis yang digunakan yaitu Structural Equation Modeling (SEM) dengan menggunakan Partial Least Square (PLS). Hasil penelitian ini menunjukkan bahwa sikap, persepsi manfaat, persepsi kemudahan penggunaan, norma subjektif, dan persepsi kontrol perilaku mempengaruhi minat penggunaan e-money, sementara persepsi risiko kinerja, risiko sosial, risiko waktu, risiko keuangan, dan risiko keamanan tidak menunjukkan adanya pengaruh terhadap minat penggunaan $e$-money.
\end{abstract}

Kata kunci: Model Penerimaan Teknologi (TAM), Teori Perilaku Rencanaan (TPB), Uang Elektronik, Persepsi Risiko

Abstract : Factors That Influence Electronic Money Intention of Use : An Integration of TAM TPB Models with Perceived Risk. The purpose of this research was to determine the factors influencing e-money intention of use. The type of this research is quantitative research. The research sample was 260 respondents of the Yogyakarta State University students. Samples were taken using convinience sampling technique. The analytical method used is Structural Equation Modeling (SEM) using Partial Least Square (PLS). The results of this research indicate that attitudes, perceived benefits, perceived ease of use, subjective norms, and perceptions of behavioral control influence e-money intention of use, while perceptions of performance risk, social risk, time risk, financial risk, and security risk do not indicate an influence on e-money intention of use.

Keywords: Technology acceptance model (TAM), Theory of planned behavior (TPB), Electronic Money, Perceived Risk

\section{PENDAHULUAN}

Perkembangan teknologi yang pesat di era digital saat ini berhasil merubah pola hidup dan sistem pembayaran transaksi ekonomi di dalam masyarakat. Semakin berkembangnya komputer dan meluasnya akses jaringan internet, penciptaan sistem layanan pembayaran yang semakin efisien menjadi semakin mungkin untuk dilakukan.

Bank Indonesia (2011) menyatakan bahwa pemakaian uang tunai memiliki kendala dalam hal efisiensi, hal itu dikarenakan adanya pengadaan dan pengelolaan (cash handling), efisiensi waktu, dan risiko keamanan. Oleh karena 


\section{JURNAL NOMINAL / VOLUME VIII NOMOR 2 / TAHUN 2019}

itu, Bank Indonesia mengeluarkan kebijakan Less Cash Society yang dikeluarkan pada periode tahun 2005-2006. Kebijakan ini bertujuan untuk mengurangi penggunaan instrumen uang tunai yang telah lama diterapkan pada kegiatan transaksi masyarakat.

E-money merupakan uang yang bisa ditransfer secara elektronik dari pembeli kepada penjual (Popovska, 2014). Tujuan dari e-money adalah sebagai alat pembayaran dapat memberikan manfaat berupa memberikan kemudahan dan kecepatan dalam melakukan transaksi transaksi pembayaran tanpa perlu membawa uang tunai. Penggunaan $e$-money berbeda dengan kartu kredit dan debit yang harus terhubung dengan rekening bank nasabah. Namun, e-money memiliki sistem berbeda, yaitu dengan sistem prabayar.

Pada tahun 2007, Bank Indonesia mulai mengatur penggunaan uang elektronik ke dalam APMK (Alat Pembayaran dengan Menggunakan Kartu). Bank Indonesia mencatat jumlah transaksi pada tahun 2007 berkisar 586.046 transaksi dan di tahun 2008 meningkat sebanyak 2.560.591 transaksi. Kemudian di tahun 2009, Bank Indonesia sebagai lembaga yang mempunyai otoritas moneter mengeluarkan Peraturan Bank Indonesia dengan No.11/12/PBI/2009 tentang Uang Elektronik (Electronic Money). Peraturan ini menjadikan pengaturan mengenai Uang
Elektronik terpisah dengan pengaturan mengenai Alat Pembayaran dengan Menggunakan Kartu. Kemudian disempurnakan kembali pada Peraturan Bank Indonesia Nomor 18/17/PBI/2016 tentang Perubahan Kedua Atas Peraturan Bank Indonesia Nomor 11/12/PBI/2009 tentang Uang Elektronik (Electronic Money), yang selanjutnya disebut dengan PBI Uang Elektronik. Tertanggal 27 September 2016, BI juga telah mengeluarkan Surat Edaran Bank Indonesia Nomor 18/21/DKSP tentang Perubahan atas Surat Edaran Bank Indonesia Nomor 16/11/DKSP tanggal 22 Juli 2014 perihal Penyelenggaraan Uang Elektronik (Electronic Money).

E-money dapat dikatakan menuju ke arah positif dikalangan masyarakat, terutama mahasiswa. Mahasiswa sebagai kaum terpelajar memiliki sifat terbuka terhadap perkembangan teknologi. Jenjang pendidikan tinggi menjadikan mahasiswa sebagi agen perubahan dituntut untuk melakukan hampir sebagian pekerjaannya menggunakan produk-produk teknologi yang sudah meluas di kalangan mahasiswa, termasuk dalam sistem pembayaran yang mereka gunakan.

Sistem pembayaran non tunai banyak diminati oleh kalangan mahasiswa terutama karena faktor manfaat yang didapatkan seperti proses pembayaran yang lebih cepat dan mudah. Penelitian sebelumnya 


\section{JURNAL NOMINAL / VOLUME VIII NOMOR 2 / TAHUN 2019}

menemukan bahwa alasan mahasiswa mengadopsi teknologi pembayaran non tunai adalah lebih cepat dalam penyelesaian pembayaran, efisien, dan keuntungan berupa diskon yang didapat saat digunakan di merchant-merchant tertentu (Ma'ruf, 2016).

Minat individu dalam menggunakan $e$ money mampu diukur menggunakan teori yang dapat mendeskripsikan tingkat penerimaan dan penggunaan terhadap suatu teknologi. Dalam penelitian ini teori penerimaan yang digunakan yaitu teori gabungan antara Technology Acceptance Model (TAM) yang dikembangkan oleh Davis (1986) dan Theory of Planned Behavioral (TPB) yang dikembangkan oleh Ajzen (1991). Melalui teori gabungan TAM dan TPB, dapat dipahami bahwa reaksi dan persepsi pengguna terhadap teknologi dapat mempengaruhi sikapnya dalam penerimaan penggunaan teknologi. Teori gabungan antara TAM dan TPB digunakan karena pada model TAM pengaruh dari faktor sosial dan faktor kontrol dalam perilaku tidak dimasukkan. Padahal faktor-faktor tersebut sebenarnya sudah ditemukan mempunyai pengaruh yang signifikan terhadap perilaku penggunaan teknologi informasi (Lisa, 2015). Selain menggunakan teori TAM dan TPB, penelitian ini menambahkan teori perceived risk. Teori tersebut terdiri dari persepsi kinerja, persepsi sosial, persepsi waktu, persepsi keuangan, dan persepsi keamanan.

Model integrasi TAM dan TPB dengan perceived risk dipilih mengingat e-money merupakan sebuah inovasi baru dalam bidang pembayaran, yang mana inovasi menyangkut finansial individu merupakan hal yang sensitif dan penting untuk melihat aspek risiko yang mungkin muncul. Integrasi dari ketiga model tersebut dimaksudkan untuk menyediakan model yang lebih komprehensif dalam menganalisis penerimaan dan niat menggunakan $e$-money.

Pembahasan masalah di atas menjadi dasar bagi peneliti melakukan penelitian mengenai faktor-faktor yang menentukan minat penggunaan e-money dengan judul "Faktor - Faktor yang Mempengaruhi Minat Penggunaan Electronic Money: Integrasi Model TAM - TPB dengan Perceived Risk"

\section{KAJIAN LITERATUR}

TPB yang mendasari upaya TRA telah terbukti berhasil dalam memprediksi dan menjelaskan perilaku manusia di berbagai teknologi informasi (Ajzen, 1991). Menurut TPB, perilaku aktual seseorang dalam melakukan tindakan tertentu secara langsung dipengaruhi oleh minat perilakunya dan pada gilirannya, secara bersama-sama ditentukan oleh sikap, norma subyektif dan persepsi kontrol perilaku 


\section{JURNAL NOMINAL / VOLUME VIII NOMOR 2 / TAHUN 2019}

terhadap pelaksanaan perilaku tersebut. Singkatnya, didasarkan pada upaya TRA, TPB diusulkan untuk menghilangkan keterbatasan model asli dalam berurusan dengan perilaku di mana orang memiliki kontrol kehendak yang tidak lengkap (Azjen, 1991).

H1: Sikap berpengaruh positif terhadap minat penggunaan e-money

H2: Norma Subjektif berpengaruh positif terhadap minat penggunaan $e$-money

H3: Persepsi Kontrol Perilaku berpengaruh positif terhadap minat penggunaan e-money

TAM adalah adaptasi dari teori tindakan beralasan (TRA) oleh Fishbein dan Ajzen (1975) dan terutama dirancang untuk memodelkan penerimaan pengguna terhadap teknologi informasi (Davis et al., 1989). Model ini berhipotesis bahwa penggunaan sistem secara langsung ditentukan oleh minat untuk menggunakan, yang pada gilirannya dipengaruhi oleh sikap pengguna terhadap penggunaan sistem dan persepsi kebermanfaatan dari sistem. Sikap dan persepsi kebermanfaatan juga dipengaruhi oleh persepsi kemudahan penggunaan. Daya tarik model ini terletak pada bahwa ia bersifat spesifik dan menampilkan kekuatan prediksi tingkat tinggi dari penggunaan teknologi (Taylor dan Todd, 1995).

H4: Persepsi kebermanfaatan berpengaruh positif terhadap minat penggunaan e-money

H5: Persepsi kebermanfaatan berpengaruh positif terhadap sikap

H6: Persepsi kemudahan penggunaan berpengaruh positif terhadap sikap

H7: Persepsi kemudahan penggunaan berpengaruh positif terhadap persepsi kebermanfaatan

Perceived risk berarti keyakinan subjektif individu tentang potensi konsekuensi negatif dari keputusan yang diambil oleh konsumen. Perceived Risk dibagi menjadi lima dimensi, yaitu Risiko Kinerja, Risiko Sosial, Risiko Waktu, Risiko Keuangan, dan Risiko Keamanan (Featherman, 2003). Bauer (1960) mendefinisikan perceived risk sebagai ketidakpastian mengenai konsekuensi yang mungkin timbul dari penggunaan produk atau jasa. Hal tersebut menyiratkan bahwa tingkat risiko yang dirasakan seseorang dan toleransi mereka sendiri untuk pengambilan risiko merupakan faktor yang mempengaruhi sikap seseorang dalam mengambil keputusan untuk melakukan atau tidak melakukan perilaku tertentu.

H8: Risiko Kinerja berpengaruh negatif terhadap sikap

H9: Risiko Sosial berpengaruh negatif terhadap sikap

H10: Risiko Sosial berpengaruh negative terhadap norma subjektif 


\section{JURNAL NOMINAL / VOLUME VIII NOMOR 2 / TAHUN 2019}

H11: Risiko waktu berpengaruh negatif terhadap sikap

H12: Risiko keuangan berpengaruh negatif terhadap sikap

H13: Risiko keamanan berpengaruh negatif terhadap sikap

\section{METODE PENELITIAN}

\section{Jenis Penelitian}

Penelitian ini menggunakan pendekatan kuantitatif. Penelitian kuantitatif adalah penelitian yang berkonsentrasi dalam pengujian teori - teori melalui variabel penelitian dalam bentuk angka dan kemudian melakukan analisa data dengan proses statistika baik manual maupun dengan peranti lunak komputer.

\section{Waktu dan Tempat Penelitian}

Penelitian ini dilakukan di Universitas Negeri Yogyakarta. Waktu pelaksanaan penelitian ini dilakukan pada bulan JanuariFebruari 2019.

\section{Subjek Penelitian}

Populasi dalam penelitian ini adalah mahasiswa Universitas Negeri Yogyakarta angkatan 2015 sampai dengan 2018 yang menggunakan e-money. Penelitian ini menggunakan teknik convinience sampling yaitu peneliti memilih partisipan karena mereka mau dan bersedia diteliti.

\section{Prosedur}

Penelitian dilakukan dengan menyebar instrumen penelitian berupa kuesioner yang berisi pertanyaan-pertanyaan yang ditujukan kepada responden yaitu mahasiswa Universitas Negeri Yogyakarta angkatan 2015 sampai dengan 2018 yang menggunakan $e$-money.

\section{Data, dan Teknik Pengumpulan}

Data yang digunakan dalam penelitian ini adalah data primer. Teknik yang digunakan untuk mengumpulkan data yaitu menggunakan kuesioner yang dibuat secara online menggunakan google form.

Kuesioner terdiri dari dua bagian, yaitu: Bagian pertama adalah pertanyaan mengenai data pribadi responden yang akan dijaga kerahasiannya. Bagian kedua adalah beberapa item pertanyaan untuk menguji variabel penelitian dengan skala Likert yang diambil dan dimodifikasi dari kuesioner penelitian Lee (2008).

\section{Teknik Analisis Data}

Uji validitas dan uji reliabilitas dalam penelitian ini dilakukan pada seluruh data yang diperoleh yaitu 260 responden. Dalam pengujian instrumen, penelitian ini menggunakan uji coba terpakai. Metode analisis yang digunakan yaitu Structural Equation Modeling (SEM) dengan menggunakan Partial Least Square (PLS).

\section{HASIL PENELITIAN DAN \\ PEMBAHASAN}

\section{Hasil}

Berikut ringkasan hasil uji analisis regresi liniear berganda: 


\section{JURNAL NOMINAL / VOLUME VIII NOMOR 2 / TAHUN 2019}

Tabel 1. Hasil Path Coefficients

\begin{tabular}{|c|c|c|c|}
\hline Hipotesis & $\begin{array}{c}\text { Original } \\
\text { Sample } \\
\text { (O) }\end{array}$ & $\begin{array}{c}T \\
\text { Statistics }\end{array}$ & $\begin{array}{c}P \\
\text { Values }\end{array}$ \\
\hline $\mathrm{ATB} \rightarrow \mathrm{BI}$ & 0,274 & 3,683 & 0,000 \\
\hline $\mathrm{SN} \rightarrow \mathrm{BI}$ & 0,221 & 4,352 & 0,000 \\
\hline $\mathrm{PBC} \rightarrow \mathrm{BI}$ & 0,137 & 2,146 & 0,032 \\
\hline $\mathrm{PU} \rightarrow \mathrm{BI}$ & 0,204 & 2,793 & 0,005 \\
\hline $\mathrm{PU} \rightarrow \mathrm{ATB}$ & 0,461 & 7,225 & 0,000 \\
\hline $\begin{array}{l}\mathrm{PEOU} \rightarrow \\
\mathrm{ATB}\end{array}$ & 0,273 & 4,555 & 0,000 \\
\hline $\begin{array}{l}\text { PEOU } \rightarrow \\
\text { PU }\end{array}$ & 0,566 & 12,806 & 0,000 \\
\hline $\mathrm{PR} \rightarrow \mathrm{ATB}$ & 0,045 & 0,805 & 0,421 \\
\hline $\mathrm{SR} \rightarrow \mathrm{ATB}$ & 0,537 & 1,429 & 0,154 \\
\hline $\mathrm{SR} \rightarrow \mathrm{SN}$ & 0,037 & 0,411 & 0,681 \\
\hline $\mathrm{TR} \rightarrow \mathrm{ATB}$ & $-0,141$ & 0,493 & 0,622 \\
\hline $\mathrm{FR} \rightarrow \mathrm{ATB}$ & $-0,369$ & 1,122 & 0,262 \\
\hline $\begin{array}{l}\text { SSR } \rightarrow \\
\text { ATB }\end{array}$ & $-0,054$ & 0,777 & 0,438 \\
\hline
\end{tabular}

Sumber : Data Primer, diolah 2019

Hipotesis 1 diterima karena nilai koefisien korelasi memiliki nilai positif sebesar 0,274 dan nilai signifikansi sebesar 0,000 yang berarti kurang dari 0,05. Artinya, sikap berpengaruh positif terhadap minat menggunakan e-money.

Hipotesis 2 diterima karena nilai koefisien korelasi memiliki nilai positif sebesar 0,221 dan nilai signifikansi sebesar 0,000 yang berarti kurang dari 0,05 . Artinya, norma subjektif berpengaruh positif terhadap minat menggunakan $e$ money.

Hipotesis 3 diterima karena nilai koefisien korelasi memiliki nilai positif sebesar 0,137 dan nilai signifikansi sebesar 0,032 yang berarti kurang dari 0,05. Artinya, persepsi kontrol perilaku berpengaruh positif terhadap minat menggunakan e-money.

Hipotesis 4 diterima karena nilai koefisien korelasi memiliki nilai positif sebesar 0,204 dan nilai signifikansi sebesar 0,005 yang berarti kurang dari 0,05. Artinya, persepsi kebermanfaatan berpengaruh positif terhadap minat menggunakan e-money.

Hipotesis 5 diterima karena nilai koefisien korelasi memiliki nilai positif sebesar 0,461 dan nilai signifikansi sebesar 0,000 yang berarti kurang dari 0,05. Artinya, persepsi kebermanfaatan berpengaruh positif terhadap sikap.

Hipotesis 6 diterima karena nilai koefisien korelasi memiliki nilai positif sebesar 0,273 dan nilai signifikansi sebesar 0,000 yang berarti kurang dari 0,05. Artinya, persepsi kemudahan penggunaan berpengaruh positif terhadap sikap.

Hipotesis 7 diterima karena nilai koefisien korelasi memiliki nilai positif sebesar 0,566 dan nilai signifikansi sebesar 0,000 yang berarti kurang dari 0,05. Artinya, persepsi kemudahan penggunaan berpengaruh positif terhadap persepsi kebermanfaatan.

Hipotesis 8 ditolak karena nilai signifikansinya sebesar 0,421 yang berarti lebih dari 0,05 sehingga persepsi risiko kinerja tidak berpengaruh terhadap sikap.

Hipotesis 9 ditolak karena nilai signifikansinya sebesar 0,154 yang berarti 


\section{JURNAL NOMINAL / VOLUME VIII NOMOR 2 / TAHUN 2019}

lebih dari 0,05 sehingga persepsi risiko sosial tidak berpengaruh terhadap sikap.

Hipotesis 10 ditolak karena nilai signifikansinya sebesar 0,681 yang berarti lebih dari 0,05 sehingga persepsi risiko sosial tidak berpengaruh terhadap norma subjektif.

Hipotesis 11 ditolak karena nilai signifikansinya sebesar 0,622 yang berarti lebih dari 0,05 sehingga persepsi risiko waktu tidak berpengaruh terhadap sikap.

Hipotesis 12 ditolak karena nilai signifikansinya sebesar 0,262 yang berarti lebih dari 0,05 sehingga persepsi risiko keuangan tidak berpengaruh terhadap sikap.

Hipotesis 13 ditolak karena nilai signifikansinya sebesar 0,438 yang berarti lebih dari 0,05 sehingga persepsi risiko keamanan tidak berpengaruh terhadap sikap.

\section{Pembahasan}

Hasil penelitian ini menunjukkan bahwa sikap berpengaruh positif terhadap minat menggunakan e-money. Hasil tersebut sesuai dengan penelitian Lee (2008) dan Ma'ruf(2016) yang menyatakan bahwa sikap terhadap penggunaan teknologi berpengaruh positif terhadap minat menggunakan teknologi (Jogiyanto, 2007). Secara logis dapat dinyatakan bahwa semakin positif sikap responden terhadap produk e-money maka akan semakin menaikkan minat responden untuk menggunakan produk e-money.

Norma Subjektif berpengaruh positif terhadap minat menggunakan e-money.
Hasil dari penelitian ini sesuai dengan hasil penelitian yang dilakukan oleh Venkatesh et al., (2003), Patel (2016), dan Lee (2008). Penelitian mereka menyimpulkan pengaruh sosial mengandung arti bahwa perilaku individu dipengaruhi oleh cara mereka percaya dengan orang lain untuk berminat menggunakan suatu teknologi. Secara singkat dapat dikatakan bahwa responden menggunakan e-money karena ada pengaruh dari teman atau keluarga mereka.

Persepsi kontrol perilaku berpengaruh positif terhadap minat menggunakan $e$ money. Hasil penelitian ini sesuai dengan teori yang telah dijelaskan bahwa semakin besar persepsi kontrol perilaku, maka semakin kuat minat seseorang untuk menggunakan teknologi (Jogiyanto, 2007). Hal ini dapat dijelaskan bahwa responden memiliki kontrol perilaku yang positif yaitu memiliki pengetahuan yang cukup, kemampuan yang baik dalam menggunakan e-money, dan sumber daya yang dimiliki untuk menggunakan produk e-money yang pada akhirnya mempengaruhi minat responden untuk menggunakan produk e-money. Hasil penelitian ini sejalan dengan penelitian yang dilakukan oleh Lee (2008) dan Ma'ruf (2016).

Persepsi kebermanfaatan berpengaruh positif terhadap minat menggunakan $e$ money. Hasil penelitian ini sesuai dengan teori yang menyatakan bahwa konstruk 


\section{JURNAL NOMINAL / VOLUME VIII NOMOR 2 / TAHUN 2019}

persepsi kebermanfaatan merupakan konstruk yang paling banyak signifikan dan penting mempengaruhi minat (Jogiyanto, 2007). Dapat diasumsikan bahwa responden merasa produk e-money yang mereka gunakan sangat memberikan manfaat lebih sehingga hal tersebut mempengaruhi minat menggunakan produk e-money. Hasil penelitian ini sejalan dengan penelitian yang dilakukan oleh Lee (2008) dan Patel (2006).

Persepsi kebermanfaatan berpengaruh positif terhadap sikap. Hasil penelitian ini sesuai dengan penelitian Lee (2008) dan Ma'ruf (2016) yang menunjukkan bahwa persepsi kebermanfaatan berpengaruh positif signifikan terhadap sikap. Dapat diasumsikan bahwa para responden merasa percaya bahwa menggunakan produk $e$ money bermanfaat bagi mereka, sehingga para responden menggunakannya.

Persepsi kemudahan penggunaan berpengaruh positif terhadap sikap. Hasil penelitian ini sesuai dengan penelitian sebelumnya yang menunjukkan bahwa konstruk persepsi kemudahan penggunaan mempengaruhi sikap (Lee, 2008). Hal ini sesuai dengan pengertian persepsi kemudahan penggunaan (PEOU) yaitu sejauh mana seseorang percaya bahwa menggunakan suatu teknologi baru akan bebas dari usaha. Dapat diasumsikan bahwa para responden merasa percaya bahwa menggunakan produk e-money memudahkan transaksi mereka, sehingga para responden menggunakannya.

Persepsi kemudahan penggunaan berpengaruh positif terhadap persepsi kebermanfaatan. Hasil penelitian ini sesuai dengan teori dan penelitian yang dilakukan oleh Lee (2008) dan Mahendra et al (2017) yang menunjukkan bahwa konstruk persepsi kemudahan penggunaan mempengaruhi persepsi manfaat. Semakin tinggi persepsi kemudahan penggunaan produk e-money maka akan semakin tinggi juga persepsi manfaat produk tersebut. Secara logis dapat digambarkan bahwa sistem atau produk yang semakin mudah dalam penggunaannya akan lebih memberikan kegunaan dan manfaat.

Persepsi risiko kinerja tidak mempengaruhi sikap. Hasil penelitian ini sesuai dengan penelitian yang dilakukan oleh Retno (2012) namun tidak sejalan dengan penelitian Lee (2008). Hal ini dapat dijelaskan bahwa tidak berfungsinya $e$ money dengan baik tidaklah mempengaruhi sikap responden untuk menggunakan atau tidak menggunakan e-money. Penjelasan mengenai mengapa risiko kinerja tidak signifikan, mungkin karena berdasarkan pengalaman penggunaan responden atas $e$ money dan pengalaman orang lain, e-money ini bisa diandalkan dan kinerja e-money tidak mengkhawatirkan responden (Retno, 2012). 


\section{JURNAL NOMINAL / VOLUME VIII NOMOR 2 / TAHUN 2019}

Persepsi risiko sosial tidak mempengaruhi sikap. Hasil penelitian ini sesuai dengan penelitian yang dilakukan oleh Masoud (2013). Hasil ini menunjukkan bahwa apapun risiko sosial yang diterima, tidak akan mempengaruhi sikap responden untuk menggunakan atau tidak menggunakan e-money (Ana, 2013). Penjelasan lain yang mungkin adalah bahwa keputusan untuk menggunakan $e$ money bersifat sukarela dan bukan keharusan.

Persepsi risiko sosial tidak mempengaruhi norma subjektif. Hasil penelitian ini sesuai dengan penelitian yang dilakukan oleh Ana (2013). Dapat disimpulkan bahwa kemungkinan terjadinya risiko sosial ketika menggunakan e-money tidaklah mempengaruhi lingkungan sekitar untuk mendorong responden tersebut untuk menggunakan atau tidak menggunakan $e$ money. Responden yang memutuskan untuk menggunakan e-money tidak akan malu atau menyesal meskipun e-money yang digunakan tidak disukai oleh teman ataupun keluarga karena produk e-money tersebut memang benar-benar disukai dan diinginkan (Ana, 2013).

Persepsi risiko waktu tidak mempengaruhi sikap. Hasil penelitian ini sesuai dengan penelitian yang dilakukan oleh Masoud (2013). Hasil ini menyiratkan bahwa pengguna e-money tidak khawatir tentang lamanya waktu yang dibutuhkan dalam memperbaiki kesalahan pembayaran yang mungkin terjadi. Responden juga tidak mempermasalahkan seberapa lama waktu mereka untuk mempelajari cara menggunakan $e$-money. Hal tersebut dapat dimungkinkan bahwa responden sangatlah yakin dengan produk e-money yang mereka gunakan, responden tidak mempermasalahkan lamanya waktu mereka untuk belajar menggunakan $e$ money ataupun seberapa lama untuk memperbaiki kesalahan pembayaran, karena $e$-money tersebut memang berguna bagi mereka.

Persepsi risiko keuangan tidak berpengaruh terhadap sikap. Hasil penelitian ini sesuai dengan penelitian yang dilakukan oleh Mamman et al. (2015). Dapat diasumsikan bahwa responden merupakan mahasiswa yang sebagian besar belum bekerja dan belum memiliki pendapatan sendiri, sehingga cenderung tidak pernah bertransaksi keuangan dengan jumlah besar, sehingga tidak terlalu mempermasalahkan risiko keuangan yang mungkin terjadi (Mamman, 2015).

Persepsi risiko keamanan tidak mempengaruhi sikap. Hasil penelitian ini sesuai dengan penelitian yang dilakukan oleh Zhang et al (2012). Hal ini menunjukkan bahwa responden tidak terlalu khawatir mengenai penipuan dan pencurian identitas yang mana bisa jadi 


\section{JURNAL NOMINAL / VOLUME VIII NOMOR 2 / TAHUN 2019}

responden sudah percaya dengan produk $e$ money yang dipakai sehingga tidak mempangaruhi sikap responden untuk menggunakan e-money. Konsumen sekarang biasanya memandang keamanan dan privasi sebagai persyaratan dasar (Zhang et al, 2012). Hal tesebut dapat membantu menjelaskan mengapa risiko keamanan tidak berdampak signifikan terhadap sikap responden untuk menggunakan e-money.

\section{SIMPULAN DAN SARAN}

\section{Simpulan}

Penelitian ini menunjukkan bahwa sikap, persepsi manfaat, persepsi kemudahan penggunaan, norma subjektif, dan persepsi kontrol perilaku mempengaruhi minat responden untuk menggunakan $e$-money, sementara persepsi risiko kinerja, risiko sosial, risiko waktu, risiko keuangan, dan risiko keamanan tidak menunjukkan adanya pengaruh terhadap minat penggunaan e-money. Maka dari itu, dapat dikatakan bahwa responden berminat menggunakan e-money dengan mengabaikan aspek risiko yang mungkin muncul

\section{Saran}

Bagi penelitian selanjutnya, sebaiknya dapat menyempurnakan model penelitian seperti menambahkan teori pendukung atau variabel tambahan dan jumlah sampel yang lebih besar. Selain itu, bisa mencoba model penelitian ini pada objek penelitian yang lain.

Bagi perusahaan penerbit e-money, Penelitian ini bisa menjadi rekomendasi bagi perusahaan untuk melakukan evaluasi implementasi e-money di Indonesia sehingga penyelenggaraan $e$-money saat ini bisa disesuaikan dengan kondisi masyarakat di Indonesia sekarang.

\section{A. DAFTAR PUSTAKA}

Ajzen, I. (1991). The Theory of Planned Behavior. Organizational Behavior and Human Decision Processes (50:2), pp. 179-211

Ana T. (2013). Pengaruh Dimensi-dimensi Persepsi Risiko terhadap Keputusan Pembelian. Skripsi. Universitas Kristen Satya Wacana.

Bank Indonesia. (2009). Peraturan Bank Indonesia No.11/12/PBI/2009 - Uang Elektronik (Electronic Money). Bank indonesia. Diakses pada laman http://www.bi.go.id/id/

Bank Indonesia (2011). Sistem Pembayaran di Indonesia. Tersedia di http://www.bi.go.id

Bauer RA. (1960). Consumer Behaviour as Risk Taking. In dynamic marketing for a changing 905 world. Chicago: American Marketing Association

Davis, F.D, Bagozzi dan Warshaw. (1989). User Acceptance of Computer Technology: A Comparison of Two Theoritical Models. Journal of Management Science Vol. 35

Featherman, M. S. \& Paul A. Pavlou. (2003). Predicting e-services adoption : a perceived risk facets perspective. International Journal of Human Computer Studies.

Fishbein M, Ajzen I. (1975). Belief, intention and behavior: an 


\section{JURNAL NOMINAL / VOLUME VIII NOMOR 2 / TAHUN 2019}

introduction to theory and research. Addison Wesley

Jogiyanto. (2007). Sistem Informasi Keperilakuan: Edisi Revisi. Andi Offset Yogyakarta

Lee, Ming-Chi. (2008). "Predicting and explaining the adoption of online trading: An empirical study in Taiwan". Decision Support Systems 47, 133-142

Lisa. (2015). Analisis Faktor-faktor penerimaan Penggunaan Quiperschool.com dengan Menggunakan Pendekatan Technology Acceptance Model (TAM) dan Theory of Planned Behavior (TPB) di SMA 7 Yogyakarta. Skripsi. Universitas Negeri Yogyakarta.

Ma'ruf, A (2016). Minat Penggunaan Produk E-money di Kalangan Mahasiswa Yogyakarta. Skripsi. Universitas Islam Negeri Sunan Kalijaga.

Mahendra, A \& A, Fajar (2017). Effects of Technology Readiness Towards Acceptance of Mandatory Web-Based Attendance System. Universitas Negeri Yogyakarta

Mamman H, Maidawa M, Saleh M. (2015). Effects of perceived risk on online shopping. Proceedings of the $1 s t$ Management, Technology, and Development Conference 4th -5 th November.

Masoud, Ernad Y. (2013). The Effect of Perceived Risk on Online Shopping in Jordan. European Journal of Bussiness and Management Vol.5 No.6

Patel, K. J., \& Patel, H. J. (2016). Adoption of Internet Banking Services in Gujarat: An Extension of TAM with Perceived Security and Social
Influence. International Journal of Bank Marketing, 36(1), 147-169.

Popovska-Kamnar, N. (2014). The Use of Electronic Money and Its Impact on Monetary Policy. Jcebi, 1(2), 79-92.

Retno W. (2012). Dimensi-Dimensi Persepsi Risiko Keseluruhan Konsumen. Skripsi. STIE YKPN

Taylor, S and Todd, P.A. (1995). Understanding Information Technology Usage: A Test of Competing Models. Information Systems Research. No.6, pp. 144-176.

Venkatesh, V., Morris, M. G., Davis, G. B., \& Davis, F. D. (2003). User Acceptance of Information Technology : Toward a Unified View. MIS Quarterly, 27(3), 425-478.

Zhang, L., Tan,W., Xu, Y. \& Tan, G. (2012) Dimensions of Consumers' Perceived Risk and Their Influences on Online Consumers' Purchasing Behaviour. Communications in Information Science and Management Engineering. 2(7), 8-14. 